\title{
Pemahaman Identitas dan Toleransi Keberagaman Budaya Mahasiswa Sastra Inggris UAI Melalui Puisi Multikultural Kesusasteraan Inggris: Sebuah Kajian Multikulturalisme
}

\author{
Sherien Sabbah ${ }^{1}$, Paramita Ayuningtyas ${ }^{2}$ \\ ${ }^{1,2}$ Program Studi Sastra Inggris, Fakultas Sastra ,Universitas Al Azhar Indonesia, Jl. \\ Sisingamangaraja, Kompleks Masjid Agung Al Azhar, Kebayoran Baru, Jakarta 12110 \\ Penulis untuk Korespondensi/Email: sherien.sabbah@uai.ac.id,
}

\begin{abstract}
Abstrak - Penelitian ini dilakukan untuk melihat respon mahasiswa Sastra Inggris UAI dalam memahami konflik keberagaman dan pemahaman identitas budaya terkait dengan ideologi multikulturalisme melalui puisi multikultural kesusasteraan Inggris. Penelitian ini merupakan penelitian kualitatif dengan menggunakan metode reader-response (respon pembaca) dengan subjek penelitian yaitu mahasiswa Sastra Inggris UAI yang mengambil mata kuliah Pengkajian Puisi sebanyak 26 orang. Dengan menggunakan teori Identitas oleh Stuart Hall sebagai kajian multikulturalisme dan teori intrinsik puisi, penelitian ini diharapkan dapat memberikan gambaran jelas mengenai respon mahasiswa Sastra Inggris terhadap teks-teks sastra bertema multikultural dan juga gambaran jelas sejauh mana pemahaman lintas budaya mereka. Pada akhirnya hasil ini secara garis besar menunjukkan bahwa pemahaman keberagaman, kepedulian sosial dan toleransi di kalangan mahasiswa sastra Inggris UAI belum baik karena sebanyak $53.86 \%$ responden terlihat mengalami kesulitan untuk memahami dan menginterpretasikan isi puisi serta tidak bisa mengaitkan tema puisi dengan kondisi keberagaman di kehidupan mereka sehari-hari.
\end{abstract}

Kata Kunci - Multikulturalisme, Identitas Budaya, Identitas Budaya, Tanggapan Pembaca

Abstract - This research is done to see the English Department students' response in understanding cultural identity and issues of differences related to the ideology of multiculturalism through interpreting a multicultural poem in English. This research is a qualitative research implementing a reader-response method using 26 students of the English Department in UAI as the subject of research. By conducting Stuart Hall's theory of Identity as a multiculturalism analysis and theory of Poetic devices, this research is done to give a clear perspective on the students' response towards a multicultural theme in a literary text as well as giving view on their intercultural understanding. In the end, this research shows that overall these students' understanding towards the issue of differences and tolerance is unsatisfying seeing that $53.86 \%$ respondents were unable to understand and interprete the poem as well as were unable to relate the theme of the poem to the condition around them in reality.

Keywords - Multiculturalism, Cultural Identity, Poetic Devices, Reader's Respond, Stuart Hall

\section{PENDAHULUAN}

Latar Belakang Masalah

$\mathrm{M}$ ulticultural Literature adalah salah satu cabang ilmu dan kajian di dalam kesusasteraan Inggris yang sedang berkembang pesat saat ini terutama sejak 30 tahun terakhir. Pada awalnya karya sastra multikultural di Amerika Serikat lahir sejalan dengan munculnya gerakan yang memperjuangkan keadilan dan pengakuan akan keberagaman dalam masyarakat. Pada awal 1980-an, istilah 
multikulturalisme mulai diperkenalkan untuk menggugat dominasi budaya WASP (White Anglo-Saxon Protestant) dalam berbagai bidang, termasuk pendidikan, bahasa, sejarah, dan ekspresi budaya di media massa dan kesusasteraan. (Budianta, 2003: 8). Pada dasarnya karya sastra multikultural dan kajian multikulturalisme lahir sebagai reaksi terhadap kondisi keberagaman serta lintas budaya yang ada. Dalam hal ini, kesusasteraan memegang peran penting sebagai wadah ekspresi dan bentuk perjuangan terkait dengan berbagai masalah dalam budaya multikultural tersebut. Globalisasi memegang peran penting dalam percampuran budaya dan persinggungan antarelemen budaya yang tidak jarang menimbulkan konflik seperti konflik; agama, etnis, suku, ras, gender, dan kebangsaan.

Terkait dengan bangsa Indonesia, masyarakat Indonesia adalah masyarakat yang kaya akan perbedaan baik dari segi etnisitas, budaya, agama dan bahasa. Istilah yang tepat untuk menggambarkan kondisi ini adalah masyarakat multikultural atau plural. Kondisi keberagaman budaya ini sering menimbulkan konflik karena pemahaman atau pemikiran yang bertentangan dengan ideologi multikulturalisme yang merayakan keberagaman dengan memahami budaya sebagai entitas yang cair atau tidak berbatas tegas. Dalam ruang lingkup pendidikan (akademis) tidak jarang kita menemukan konflik-konflik terjadi terutama di kalangan mahasiswa. Pemahaman atau pandangan yang tampak secara lisan dan sikap negatif seperti stereotyping, prasangka buruk (prejudice),diskriminasi,eksklusivisme/inklusifi sme antarkelompok masih ditemukan di kalangan mahasiswa/mahasiswi. Pada taraf yang ekstrim pemahaman atau sikap yang bertentangan dengan ideologi multikulturalisme dapat terlihat dari aksi-aksi negatif seperti bullying, pelecehan baik fisik maupun verbal, senioritas berlebihan, dan sikap tidak menghargai terhadap mereka yang dianggap 'berbeda'.

Kajian terhadap persoalan ini perlu dilakukan guna untuk memahami sejauh mana pemahaman identitas budaya mahasiswa dan efektifitas pembelajaran komunikasi lintas budaya yang sudah ada dalam kurikulum. Terkait dengan permasalahan ini, pembacaan teks-teks atau karya-karya sastra multikultural menjadi penting karena dapat menjadi wadah dalam memahami perspektif dan pandangan mahasiswa sekaligus membuka wawasan mereka tentang konsep budaya yang sesuai dengan ideologi multikulturalisme-merayakan keberagaman dan menghargai perbedaan yang ada.

Sastra dan bahasa memiliki keterkaitan erat dengan budaya dan manusia. Sastra sebagai cerminan realita dan ekspresi budaya dapat dilihat sebagai aspek penting yang dapat membuka wawasan dan pemikiran terkait dengan manusia dan dunia sekitarnya. Filsuf besar Yunani, Horatius dalam bukunya Ars Poetica (dalam Teeuw, 1984:183) menyatakan bahwa tujuan penyair menulis sajak adalah memberi nikmat dan berguna (dulce et utile). Sesuatu yang memberi nikmat atau kenikmatan berarti sesuatu itu dapat memberi hiburan, menyenangkan, menenteramkan, dan menyejukan hati. Sesuatu yang berguna adalah sesuatu yang dapat memberi manfaat dan kegunaan. Puisi sebagai salah satu cabang karya sastra dapat berperan sebagai media ekspresi budaya yang dapat menjadi sarana yang kaya dengan makna yang disampaikan oleh penulisnya baik secara lansung maupun terselubung, tak terkecuali dalam menanggapi isu multikulturalisme/pluralisme.

Mahasiswa sebagai generasi muda sudah sepatutnya menjadi ujung tombak dalam memberdayakan perbedaan tersebut sebagai potensi kekayaan bangsa yang harus disikapi secara benar. Mahasiswa sebagai generasi intelektual memegang peran penting di dalam mewujudkan kondisi keberagaman yang damai. Oleh karena itu fokus penelitian ini adalah para mahasiswa dengan responden mahasiswa sastra Inggris UAI. Selain itu, target penelitian ini adalah ekspresi atau ungkapan para mahasiswa ketika diberikan topik multikultural dan harus merespon dari puisi multikultural yang dibaca. Pemilihan media ini dianggap penting karena bentuk ekspresi ini memberikan ruang bagi para mahasiswa untuk mengungkapkan responnya terhadap topik multikultural secara langsung (prosesnya) dan juga sekaligus secara terselubung (isi ekspresinya), sehingga secara tak langsung dan tak sadar setidaknya mereka akan merasa memiliki kebebasan untuk mengungkapkan pemahaman dasar mereka. Tujuan penelitian ini adalah untuk mengelaborasi respon mahasiswa yang tertuang 
melalui pembacaan puisi terhadap persoalan multikultural yang ada.

\section{Tujuan}

Penelitian ini dilakukan untuk melihat wacana mengenai kondisi masyarakat multikultural seperti apa yang dimiliki oleh mahasiswa UAI. Dari tujuan itu, berbagai masalah multikultural dapat diidentifikasi, dan diharapkan penelitian ini dapat membantu menemukan solusi untuk mengatasi konflik multikultural. Penelitian ini diharapkan dapat memberikan gambaran jelas mengenai respon mahasiswa sastra Inggris terhadap teks-teks sastra bertema multikultural dan juga gambaran jelas tentang sejauh mana pemahaman lintas budaya mereka. Penelitian ini diharapkan dapat memberikan gambaran apakah mahasiswa sastra Inggris UAI sudah memiliki konsep pemahaman lintas budaya yang sesuai dengan ideologi multikulturalisme.

\section{Perumusan Masalah}

Bagaimana mahasiswa sastra Inggris UAI merespon konflik dan memahami identitas budaya terkait dengan ideologi multikulturalisme melalui puisi-puisi multikultural kesusasteraan Inggris?

\section{KAJIAN PUSTAKA}

\section{Multikulturalisme}

Multikulturalisme dipersepsi sebagai sebuah pergerakan yang menentang dominasi aliran budaya utama pada suatu tempat tertentu dan menuntut pengakuan tertentu dari masyarakat atas keberadaannya. Multikulturalisme berkaitan erat dengan konflik dalam masyarakat yang ingin mempraktekkannya. Konflik tersebut berasal dari konsep bahwa masyarakat pada umumnya ingin berada dalam sebuah lingkungan dan situasi yang nyaman, stabil, dan menyenangkan. Multikulturalisme dapat menjadi ancaman bagi kenyamanan dan kestabilan tersebut karena gerakan tersebut berusaha menyesuaikan bahkan merombak tatanan yang sebelumnya dianggap telah disetujui bersama.

Konsep masyarakat dapat terbentuk atas dasar kesamaan-kesamaan yang ada di dalamnya, misalnya kesamaan genealogi, wilayah, kebiasaan, tradisi, nilai, dan sejarah. Ketika kestabilan masyarakat tersebut ditantang dengan masuknya kelompok-kelompok masyarakat baru atau dengan munculnya berbagai perkembangan dan pembaharuan dari dalam masyarakat itu sendiri. Perbedaanperbedaan yang terjadi dalam masyarakat tersebut menimbulkan ketimpangan dan gesekan budaya. Menurut Parekh (1997), masyarakat multikultural dapat diperlakukan dengan dua cara yaitu asimilasi serta apresiasi terhadap keanekaragaman tersebut.

First, we could say that cultures qua cultures deserve no respect. We should judge and grade them and assimilate the inferior ones into one judged to be the best. ... We may call this view monoculturalism. It is commonly associated with assimilationist policies. Secondly, we could argue that all cultures deserve respect and should enjoy the freedom and the opportunity to preserve and reproduce themselves. ... society should welcome and cherish cultural diversity. We may call such a view multiculturalism. (Parekh, 1997:169).

Cara pertama akan mematikan keanekaragaman yang ada di masyarakat tersebut karena proses asimilasi mengandalkan penilaian yang cenderung subjektif. Proses tersebut berkutat pada pengelompokkan dan penilaian kebudayaan-kebudayaan yang dianggap berbeda dan minoritas. Selanjutnya, akumulasi pemilahan berbagai kebudayaan tersebut dipadukan dalam sebuah wadah yang dianggap lebih unggul dan lebih stabil (kebudayaan mainstream). Masyarakat tersebut pada akhirnya menganut monokulturalisme.

Sebaliknya, cara kedua akan merayakan keanekaragaman budaya yang ada. Kestabilan kebudayaan mainstream tidak dapat dijadikan patokan. Yang terjadi adalah keanekaragaman budaya yang ada saling melengkapi dan menguntungkan satu sama lain. Konsep asimilasi tidak berterima karena dalam masyarakat tersebut - yang selanjutnya menganut multikulturalisme - tidak ada satu budaya tertentu yang dianggap paling baik. Sebuah kebudayaan mempunyai keunikan dan kekhasan tertentu yang tentu saja berbeda dengan kebudayaan lainnya. Perbedaan tersebut semestinya dihargai dan dibiarkan tumbuh dengan tenang. 
Sebagai contoh, menurut Gunew dalam Budianta, pendidikan multikultural di Inggris masih disesaki dengan "perspektif budaya dominan yang melihat budaya etnik kelompokkelompok minoritas" (2003:13). Kebudayaan India atau Cina ditempatkan dalam stereotipstereotip yang kaku dan dipandang "negatif". Oleh karena itu, pembelajaran tentang multikulturalisme semestinya tidak terbatas pada gambar-gambar dan penjelasan yang ditulis dalam buku-buku teks. Jika terbatas pada hal tersebut, pemahaman tentang masalahmasalah nyata di luar yang dituliskan menjadi terabaikan. Pengetahuan tersebut hanya akan menjadikan kebudayaan mainstream makin berkuasa dalam mengendalikan hal-hal apa saja yang patut diketahui dan tidak patut diketahui.

\section{Identitas Budaya}

Stuart Hall menolak definisi identitas budaya esensialis, yaitu konsep identitas budaya kolektif yang dimiliki oleh setiap individu dan dapat dirasakan bersama melalui kesamaan sejarah dan akar budaya. Identitas budaya demikian mencerminkan perjalanan sejarah dan kode-kode budaya yang dimiliki bersama dan dapat menyatukan kelompok orang sebagai satu bangsa dengan budaya yang stabil dan tidak berubah. Identitas budaya mempunyai asalusul, dan memiliki sejarah. Tetapi seperti halnya segala sesuatu yang bersifat historis, identitas budaya mengalami transformasi yang terus-menerus. Identitas budaya tidak abadi di dalam masa lalu, melainkan terbuka untuk larut dalam perubahan sejarah, kebudayaan dan kekuasaan.

Identitas menuntut kekhususan dalam persilangan kejadian dan situasi. Identitas tidak dibangun dengan upaya pengasingan atau eksklusivitas, melainkan dengan menempatkan diri pada suatu posisi dalam masyarakat. Identitas bukan hanya perkara memposisikan diri tapi juga diposisikan oleh orang lain. Identitas budaya bukanlah suatu esensi tetap. Identitas budaya menjadi masalah saat terjadi krisis, yaitu ketika sesuatu yang diasumsikan 'utuh' dan stabil tidak didapatkan dalam pencarian identitas. Hal itu dikarenakan identitas budaya yang 'utuh' dan stabil tidak ada karena identitas budaya tergantung pada bagaimana seseorang menjadikan identitas budaya itu sebagai posisi, sehingga ia dapat menjadi 'siapa saja' di mana pun ia berada. (Hall, 1997: 51).
Berdasarkan pandangannya tentang konsep identitas non-esensialis, Hall menolak pengertian identitas budaya yang bersifat permanen, kekal dan tidak berubah. Identitas budaya yang lahir dari persamaan pandangan, perasaan, karakteristik dan identifikasi terhadap berbagai kategori budaya adalah sesuatu yang tidak mungkin diwujudkan karena tiap orang mengalami pengalaman dan mengalami pencarian identitas yang berbeda-beda tergantung kondisi yang dihadapi masingmasing. (Hall dalam Woodward, 1997:10)

\section{Unsur Intrinsik Puisi}

Sebagai karya sastra, puisi mempunyai ciri khas yang membedakannya dengan prosa dan drama. Puisi pada umumnya terikat oleh aturan-aturan tentang bentuk, panjang baris, ritme dan rima (Thorne, 2006). Analisis puisi juga menjadi tantangan tersendiri karena penulis puisi berusaha menyampaikan ide mereka dengan tetap mengikuti kaidah-kaidah berpuisi. Untuk memahami isi puisi, pembaca harus membaca berulang kali dan mendalami unsur-unsur intrinsik yang menjadi kekhasan puisi.

Unsur instrik pertama puisi adalah stanza, yang merupakan kumpulan baris dalam puisi. Stanza yang terdiri dari dua baris disebut sebagai couplet, tiga baris sebagai tercet, empat baris sebagai quatrain, dan seterusnya. Selain bentuk, puisi juga menganggap bunyi sama pentingnya dengan kata-kata tertulis. Banyak bentuk puisi (seperti sonet dan villanelle) yang mengandalkan rima, atau bunyi akhir dari tiap baris. Selain berpengaruh terhadap estetika bunyi dalam puisi, pemilihan rima yang tepat juga akan menambah makna dalam puisi. Di dalam puisi, ritme juga merupakan elemen penting. Ritme akan memengaruhi cara membaca puisi dan penulis puisi juga menggunakan ritme untuk menggarisbawahi kata yang dia anggap penting. Pola ritme dalam puisi disebut sebagai metre. Metre bisa bervariasi dari satu baris ke baris lain (Thorne, 2006). Variasi metre ini juga bisa menandai perubahan mood di dalam puisi.

Elemen lain yang menjadi karakter dari puisi adalah majas atau gaya bahasa. Majas memberi ruang kepada penulis puisi untuk menyampaikan ide mereka dengan lebih puitis dan tersirat. Ada beberapa majas yang umum digunakan dalam puisi: (1) simile, ketika 
penulis membandingkan dua hal yang pada dasarnya tidak sama dan membuat perbandingan yang eksplisit dengan penggunaan kata 'seperti'. (2) Metafora, juga merupakan perbandingan dua hal, tapi metafor menerapkan perbandingan yang lebih tersirat. Contohnya adalah baris Life's but a walking shadow yang ditulis oleh Macbeth. (3) Personifikasi, gaya bahasa yang memberikan kualitas benda hidup kepada benda mati. Misalnya, penulis mengungkapkan bahwa sedang turun hujan dengan kalimat Langitnya menangis.

Puisi juga sangat memerhatikan unsur-unsur retoris yang bisa menarik perhatian pembaca terhadap ide utama puisi tersebut. Unsur retoris bisa muncul dalam bentuk repetisi, tripling dan paralelisme. Repetisi adalah pengulangan kata, frase, klausa atau kalimat dengan tujuan menekankan ide yang ingin disampaikan. Salah satu fungsi repetisi adalah membangun suasana tertentu di dalam puisi. Sementara tripling adalah pengulangan struktur atau kata dengan jumlah tertentu, yaitu tiga kali. Tujuannya sama, yaitu ingin menarik perhatian pembaca terhadap ide tersebut. Terakhir adalah paralelisme, yang berarti penggunaan bunyi, kata atau struktur gramatikal lain secara berpasangan.

\section{METODE PENELITIAN}

\section{Metode}

Penelitian ini merupakan penelitian kualitatif dengan menggunakan metode reader-response (respon pembaca) dengan subjek penelitian yaitu mahasiswa Sastra Inggris UAI yang mengambil mata kuliah Pengkajian Puisi. Jumlah responden sebanyak kurang lebih 30 orang. Langkah pertama yang dilakukan dalam penelitian ini adalah merumuskan permasalahan dan metode penelitian. Selanjutnya, pengumpulan data dilakukan dengan memberikan bahan bacaan puisi berbahasa Inggris dengan tema multikulturalisme kepada responden. Setelah responden melakukan pembacaan (close reading), mereka akan diberikan kuesioner dengan pertanyaan yang berkaitan dengan isi puisi tersebut. Pertanyaan akan diberikan dalam bentuk esai sehingga responden bisa menginterpretasi isi puisi dengan lebih bebas. Jawaban dari responden ini akan menjadi data primer penelitian yang dielaborasi dengan konsep budaya Stuart Hall. Tahap akhir adalah penarikan kesimpulan mengenai pemahaman budaya multikultural mahasiswa Sastra Inggris UAI.

\section{Data dan Sumber Data}

Data primer merupakan respon mahasiswa sastra Inggris UAI sebanyak kurang lebih 30 orang dalam bentuk essay terhadap questioner dan bacaan puisi yang diberikan. Data sekunder merupakan data pustaka mengenai konsep multikulturalisme, teori identitas budaya, dan teori intrinsic kajian puisi.

\section{HASIL DAN PEMBAHASAN}

Sebelum menjawab kuesioner, responden diminta untuk membaca puisi berjudul $A$ Multicultural Town yang ditulis oleh Francis Duggan. Puisi ini dipilih karena temanya yang sesuai dengan topik penelitian ini dan kosakata yang digunakan oleh Duggan cenderung sederhana sehingga diharapkan responden bisa dengan mudah memahami puisi tersebut. Terdapat enam pertanyaan dalam kuesioner yang didistribusikan kepada responden, yaitu:

(1) How long have you studied poetry analysis?

(2) Are you used to reading poems in English? If yes, what type of poem do you usually read? (3) After reading the poem A Multicultural Town by Francis Duggan, what do you think the theme of the poem is? (4) What kind of town is described in the poem? (5) How do you perceive the multicultural condition or condition of differences in the poem? (6) How do you relate the issues of differences in the poem to the reality around you? Berikut adalah rincian dari pertanyaan dan jawaban seperti apa yang diharapkan dari pertanyaan tersebut.

Pertanyaan pertama "How long have you studied poetry analysis?" diletakkan di urutan pertama dalam kuesioner untuk mencari tahu sudah berapa lama responden mempelajari puisi. Dari pertanyaan ini, dapat diperkirakan materi tentang puisi apa yang sudah mereka terima sehingga bisa dikaitkan dengan tingkat pemahaman mereka tentang unsur-unsur yang menjadi ciri khas puisi. Pertanyaan kedua "Are you used to reading poems in English?" juga dimaksudkan untuk mencari tahu apakah responden terbiasa membaca puisi dalam bahasa Inggris. Bisa jadi di luar kelas dan 
sebelum mengambil mata kuliah Kajian Puisi, mereka sudah terbiasa membaca puisi dalam bahasa Inggris. Selain itu, pertanyaan kedua juga ingin mencari tahu jenis puisi apa yang biasa mereka baca.

Pertanyaan nomor tiga sampai pertanyaan nomor lima sudah masuk ke pemahaman responden tentang puisi A Multicultural Town. Pertanyaan ketiga bertujuan untuk mengetahui apakah setelah membaca puisi, responden dapat memahami tema yang ingin disampaikan oleh puisi tersebut. Jawaban yang diharapkan masih berupa pemahaman secara umum dan bisa disampaikan dalam setidaknya satu frasa atau satu kalimat sederhana. Sementara itu, pertanyaan keempat "What kind of town is described in the poem?" berfokus pada latar tempat yang dideskripsikan di dalam puisi. Diharapkan responden dapat menggambarkan kembali kota yang terdapat di dalam puisi dengan bahasa mereka sendiri. Pertanyaan ini bertujuan untuk melihat apakah dari diksi yang digunakan oleh penulis puisi untuk menggambarkan kota, responden dapat memahami seperti apa kota multikultural itu. Berikutnya, pertanyaan kelima menekankan pada pemahaman responden terhadap isu multikultural dan perbedaan yang terkandung di dalam puisi. Pertanyaan ini merupakan pertanyaan yang sudah masuk ke kajian yang lebih dalam terhadap isi puisi.

Pertanyaan "How do you relate the issues of differences in the poem to the reality around you?" diletakkan dalam urutan terakhir karena pertanyaan ini mengaitkan isi puisi dengan kenyataan di sekitar responden mereka. Setelah apresiasi responden terhadap tema dan isu multikultural dan perbedaan dalam puisi terjawab dalam pertanyaan ketiga sampai kelima, pertanyaan keenam berusaha untuk mencari tahu bagaimana responden bisa melihat relevansi puisi A Multicultural Town dengan lingkungan tempat tinggal mereka. Ketika kuesioner ini didistribusikan, terdapat argumen dan konflik (terutama di media sosial) mengenai kondisi keberagaman di kota Jakarta, berkaitan dengan pemilihan Gubernur dan Wakil Gubernur yang diselenggarakan pada bulan Februari dan April 2017. Akan menarik untuk melihat apakah responden akan mengikutsertakan konteks kota Jakarta dalam jawaban mereka untuk pertanyaan nomor enam.
Setelah mendistribusikan kuesioner, didapatkan jawaban dari 26 responden, yang semuanya adalah mahasiswa/mahasiswi Sastra Inggris Universitas Al Azhar Indonesia. Jawaban responden kemudian menjadi data untuk dianalisis dengan pendekatan kualitatif serta teori multikulturalisme dan dasar-dasar analisis puisi. Secara umum, data dapat dapat dibagi menjadi dua kategori: kelompok A yang menyadari kondisi keberagaman di sekitar mereka dan kelompok B yang tidak menyadari. Berdasarkan jawaban yang mereka berikan, kelompok A dapat memahami isu multikulturalisme dan perbedaan yang terkandung di dalam puisi A Multicultural Town. Mereka juga bisa mengaitkan isi puisi dengan kondisi keberagaman yang ada di sekitar mereka. Sementara itu, kelompok B terlihat mengalami kesulitan untuk memahami isi puisi secara mendalam. Mereka juga tidak melihat keterkaitan antara tema puisi dengan realita yang ada dalam kehidupan mereka sehari-hari. Penjabaran mengenai jawaban masing-masing kelompok akan dibahas berikutnya.

\section{Analisis jawaban kelompok A}

Seperti telah dijelaskan di atas jawaban responden dibagi atas dua kategori yakni kelompok A adalah mereka yang sadar akan kondisi keberagaman di sekitar mereka (aware and can relate to reality) dan kelompok B yang tidak sadar akan kondisi keberagaman di sekitar mereka (unaware and cannot relate to reality). Jumlah responden adalah 26 mahasiswa aktif semester 6 sastra Inggris UAI dengan terbagi atas $46.15 \%$ untuk kelompok A dan $53.86 \%$ untuk kelompok B. Meskipun jumlah atau presentase terbilang agak sama, namun jumlah mereka yang sadar akan kondisi keberagaman di sekitar mereka melalui puisi yang dibaca lebih sedikit yakni 12 orang.

Dari 12 orang dapat terbagi lagi atas dua kategori jawaban. Yakni mereka yang baru dapat memahami kondisi keberagaman di dalam puisi yaitu yang dapat memberikan interpretasi dari puisi yang mereka baca dengan menjabarkan bahwa kondisi kota yang terdapat di dalam puisi menunjukkan kondisi kota dengan kondisi kemajemukan dan perbedaan ras, agama, warna kulit, jender, dsb. Namun kelompok ini hanya menunjukkan bahwa mereka memahami puisi tersebut dan dapat menginterpretasikannya dengan kondisi 
multikultural. Kelompok yang berjumlah 5 $(19.2 \%)$ orang ini belum dapat menjabarkan secara detail atau mengaitkan kondisi yang mereka baca dengan realita di sekitar mereka secara detail. Sebagai contoh dapat dilihat dari responden atas nama Halimatus Sadiyah berikut ini:

Pertanyaan no. 4: After reading the poem A Multicultural Town by Francis Duggan, what do you think is the theme of the poem?

Jawaban: I think that this town describes all of cultures in different country in this poem.

Pertanyaan 5: What kind of town is described in the poem?

Jawaban: The kind of town is a multicultural.

Pertanyaan 6: How do you relate the issue of differences in the poem to the reality around you?

Jawaban: We must tolerate to each other and pay attention to it.

Dari jawaban mahasiswi di atas dapat dilihat untuk jawaban no.4 dan no.5, ia dapat memahami bahwa puisi ini memberikan gambaran kondisi keberagaman pada sebuah kota. Hal ini berarti ia memahami maksud yang ada pada puisi tersebut. Namun untuk jawaban no 6 jawaban "we must tolerate to each other..." dirasa kurang mencapai target jawaban yang diharapkan karena tidak berubah penjabaran atau interpretasi detail dengan kondisi faktual di sekitarnya. Jawaban seperti ini mengindikasikan bahwa responden ini belum dapat mengaitkan secara detail kondisi keberagaman yang ada di puisi dengan kondisi keberagaman di sekitarnya. Contoh ke dua dapat dilihat dari jawaban responden atas nama Nadia Adella berikut ini:

Pertanyaan no. 4: $\quad$ After reading the poem A Multicultural Town by Francis Duggan, what do you think is the theme of the poem?

Jawaban:
A town full of various people, various conditions, but the people seems don't represent that varies.

Pertanyaan 5: What kind of town is

Jawaban: described in the poem? It is presented as something ordinary that in a town with multicultural condition people tend to have less attention with each other and the differences among them.

Pertanyaan 6:

How do you relate the issue of differences in the poem to the reality around you?

Jawaban: It is very common in our real life, very relatable.

Dari jawaban mahasiswi di atas menunjukkan bahwa ia sudah dapat menginterprestasikan secara lebih detail kondisi keberagaman yang terdapat pada puisi, namun jawaban no 6 tidak menjelaskan secara detail seperti apa kondisi keberagaman yang terkait dengan realita di sekitar. Jawaban no 6 dari responden itu hanya menjawab bahwa memang kondisi di dalam puisi terkait erat dengan realita "It is very common in our real life, very relatable" namun tidak menjelaskan secara detail kondisi faktual seperti apa yang ia tangkap dari kondisi keberagaman di sekitarnya. Jawaban seperti ini kami kategorikan pada kelompok yang sudah memahami kondisi keberagaman pada puisi namun belum secara jelas dapat mengaitkan dengan realita di sekitarnya.

7 responden (26.92\%) dari kelompok A ini tergolong mereka yang sudah sadar akan kondisi multikultural dan dapat mengaitkan erat dengan penjabaran detail atas apa yang mereka lihat dan rasa di sekitar mereka. Kelompok jawaban ini adalah kelompok jawaban terbaik sesuai target yang diharapkan. Sebagai contoh dapat dilihat dari contoh responden atas nama Listya Dewi Anggraeni berikut ini:

Pertanyaan 5: $\quad$ What kind of town is

Jawaban: described in the poem? I can relate to what happen in the poem considering in happened in reality. 
We are being devided by our skin colour, our religion, our ideology, our belief, our race.

Pertanyaan 6: $\quad$ How do you relate the issue of differences in the poem to the reality around you?

Jawaban: $\quad$ It is relatable to what happened in Jakarta especially around us. You cannot be anything here if you are having the different religion from the majority. We are being defined by our religion in this town.

Dari jawaban di atas dapat dilihat secara jelas bahwa mahasiswi ini memahami jelas isi atau gambaran yang terdapat pada puisi. Meskipun puisi tersebut tidak menggambarkan situasi di Jakarta, namun mahasiswi ini dapat menangkap maksud dalam puisi dan mengaitkannya dengan realita keberagaman yang ada di sekitarnya. Melalui jawaban dari dua pertanyaan di atas menunjukkan kesadaran dan kepedulian akan isu identitas dan perbedaan yang memang ada pada realita. Dari jawaban mahasiswi ini menyebutkan secara jelas permasalahan identitas dan keberagaman yang ia rasa di sekitarnya terutama terkait dengan agama. Identitas dilihat dari aspek agama dan ini menjadi permasalahan ketika identitas yang melekat pada diri seseorang termasuk minoritas dalam masyarakat. Jawaban tersebut juga menyiratkan bahwa perbedaan atas faktor identitas agama dapat memosisikan secara inferior yang membuatnya sulit mengembangkan diri.

Contoh lain dari kelompok jawaban ini dapat dilihat pada jawaban responden atas nama Nadhira Ayu Yasmine berikut ini:

\section{Pertanyaan 5:}

Jawaban:
What kind of town is described in the poem?

I think the multicultural condition shows that the social life in that town is bordered by the multicultural itself; people only socialize
Pertanyaan 6:

Jawaban:

with their own kind and not mingling with other people with different race, culture and religion.

How do you relate the issue of differences in the poem to the reality around you?

I can relate the issue of differences in the poem by the condition in my own environment, because there are many diversity issues in Jakarta lately that especially nudge religion issue. To be honest, it is so ironic that our people love shouting about justice about diversity yet some of them also judge the minority race and religion like Chinese and religion.

Seperti jawaban responden sebelumnya, mahasiswi ini mengutarakan ide yang kurang lebih sama yakni sudah dapat menggambarkan secara jelas kondisi keberagaman pada puisi dengan mengungkapkan bahwa kondisi keberagaman yang tergambar bernilai negatif karena tergambar bahwa masyarakat dibatasi oleh ras, kultur, dan agama untuk saling bersosialisasi. Pada jawaban no. 6, ia sudah dapat mengaitkan dengan kondisi keberagaman disekitarnya yang melihat kondisi realita yang ada sangat ironis melihat banyaknya orang yang 'berteriak' keadilan namun di sisi lain menghakimi agama dan ras minoritas. Hal ini menunjukan pemahaman identitas dari responden yang melihat bahwa identitas di sekitarnya masih dilihat sebagai faktor penentu dalam bersosialisasi dengan sesama, faktor yang membuat seseorang merasa berhak menghakimi yang lain serta faktor yang menempatkan seseorang berada pada kedudukan yang superior atau inferior.

\section{Analisis kelompok B}

Secara keseluruhan kelompok B adalah mereka yang dikategorikan tidak sadar akan kondisi keberagaman di sekitar mereka. Jumlah ini 
adalah yang terbanyak yaitu sekitar $53.84 \% .5$ orang dari kelompok ini (19.2\%) tidak menjawab pertanyaan 5 dan 6 atau menjawab dengan jawaban "I don't really understand" dan "I don't really understand the point" (Lusi Permatasari, jawaban no.4 dan 6). Hal ini kami asumsikan bahwa selain masih mengalami kesulitan akan bahasa dalam memahami bahasa Inggris secara umum, mereka juga kemungkinan bingung dan tidak mengerti akan topik dan isu multikultural sehingga sulit menjawab pertanyaan tentang kondisi keberagaman dan apalagi mengaitkannya dengan realita di sekitar mereka. 9 orang lain (34.6\%) berusaha menjawab namun jawabannya tidak sesuai target yang diharapkan. Sebagai contoh dapat dilihat dari jawaban responden atas nama Tito Dwi Rangga Atmaja:

Pertanyaan no. 4: $\quad$ After reading the poem A Multicultural Town by Francis Duggan, what do you think is the theme of the poem?

Jawaban: Uptown/Capital City Pertanyaan 5: $\quad$ What kind of town is described in the poem?

Jawaban:

Multicultura

Condition

Pertanyaan 6: $\quad$ How do you relate the issue of differences in the poem to the reality around you?

Jawaban: $[\ldots]$ the poem always relate in the reality life of democracy state.

Jawaban responden ini menunjukan bahwa ia dapat menangkap bahwa puisi ini menunjukan kondisi multikultural namun jawaban no.4 dan no. 6 tidak sesuai dengan jawaban seharusnya. Hal ini menunjukan bahwa mahasiswa ini sebenarnya tidak memiliki permasalahan bahasa tetapi tidak dapat menginterpretasikan puisi dan tidak memahami mengenai isu multikulturalisme secara seksama. Secara keseluruhan kelompok ini tidak menjawab secara benar jawaban untuk no 4-6 dengan benar. Hal ini kami lihat disebabkan oleh faktor bahasa dan kurangnya wawasan keberagaman.

\section{KESIMPULAN DAN SARAN}

Hasil dari 26 responden yang merupakan mahasiswa/i sastra Inggris UAI semester 6 dapat dibagi menjadi dua kategori: kelompok A sebanyak $46.15 \%$ yang memahami isu multikulturalisme di dalam puisi $A$ Multicultural Town dan juga bisa mengaitkan isi puisi dengan kondisi keberagaman yang ada di sekitar mereka, serta kelompok B sebanyak $53.86 \%$ yang terlihat mengalami kesulitan untuk memahami isi puisi dan tidak bisa mengaitkan antara tema puisi dengan realita yang ada dalam kehidupan mereka sehari-hari.

Melihat bahwa para responden adalah mahasiswa/i semester 6 yang seharusnya sudah memiliki kemampuan berfikir kritis dan kemahiran bahasa cukup baik, hasil ini sayangnya tidak menunjukkan hasil yang baik. Sebanyak $53.86 \%$ mahasiswa yang menunjukkan kesulitan memahami isi puisi dan tidak bisa mengaitkan dengan kondisi keberagaman di sekitar mereka dapat dilihat karena faktor kesulitan penguasaan bahasa Inggris untuk dapat memahami wacana (19.2\%). Selain itu permasalahan ini juga diakibatkan kurangnya pengetahuan umum mereka dan kepekaan terhadap kondisi sosial di sekitar mereka. Kesulitan mengaitkan dengan kondisi keberagaman disebabkan kurangnya pengetahuan tentang kondisi dan isu multikulturalisme sendiri. Hal ini berarti sebagian besar mahsiswa dapat dikatakan memiliki pemahaman tentang multikulturalisme dan identitas serta kepekaan terhadap kondisi perbedaan dan keberagaman yang masih rendah.

Dari $46.15 \%$ mahasiswa yang dapat memahami isi puisi terkait dengan kondisi multikultural, hanya $26.92 \%$ yang benar-benar dapat mengaitkan dengan memberikan penjabaran secara detail kaitannya dengan realita keberagaman dan perbedaan di sekitar mereka. Sebanyak $19.2 \%$ baru sampai memahami isi puisi dan dapat menangkap kondisi keberagaman yang ada namun masih kesulitan mengaitkannya dengan kondisi keberagaman dan perbedaan dalam kehidupan mereka. Permasalahan ini menunjukkan bahwa dalam memahami kondisi multikultural diperlukan rasa kepekaan dan keperdulian serta wawasan yang luas akan apa yang terjadi di sekitar mereka. Untuk mereka yang baru 
sampai tahap memahami isi puisi secara benar menunjukkan bahwa mereka memahami isu multikultural secara literal, namun belum memiliki kepekaan sosial yang cukup untuk dapat mengaitkannya dengan apa yang terjadi di kehidupan mereka.

Pada akhirnya hasil ini secara garis besar menunjukkan bahwa pemahaman keberagaman, kepedulian sosial dan toleransi di kalangan mahasiswa sastra Inggris UAI belum baik. Hal yang dapat dilakukan untuk mengatasi permasalahan ini adalah dengan lebih banyak menitikberatkan kurikulum yang lebih banyak berfokus pada aspek multikulturalisme seperti memberikan materi ajar yang bisa mengasah kepekaan dan kepedulian mereka atau menyiapkan tugas/kegiatan observasi lapangan yang bisa membuat mereka turun ke lingkungan dan melihat kondisi keberagaman.

\section{DAFTAR PUSTAKA}

[1] Budianta, Melani. 2003. "Multikulturalisme dan Pendidikan Multikultural: Sebuah Gambaran Umum" dalam Tsagafah, Vo.1 1, No. 2

[2] Hall, Stuart (ed.). 1997. Representation: Cultural Representations and Signifying Practices. London: Sage Publications

[3] Parekh, Bhikhu. 1997. "National Culture and Multiculturalism". Media and Cultural Regulation. Kenneth Thompson (ed.). London: Sage Publications and the Open University.

[4] Teeuw, A. 1984. Sastera dan Ilmu Sastera. Pustaka Jaya: Jakarta

[5] Woodward, Kathryn (ed). 1997. Identity and Difference. London: Sage Publications

[6] Thorne, Sara. 2006. "Mastering Poetry". Palgrave Macmillan: Hampshire dan New York. 